\title{
Effect of Resolvin DI and EI on Mucin Expression in Human Airway Epithelial Cells
}

\author{
Hyung Geun Kim ${ }^{1}$, Tae Yeong Choi ${ }^{1}$, Chang Hoon Bae ${ }^{1}$, Yoon Seok Choi ${ }^{1}$, \\ Hyung Gyun $\mathrm{Na}^{1}$, Si-Youn Song ${ }^{1}$, and Yong-Dae Kim ${ }^{1,2}$ \\ ${ }^{I}$ Department of Otorhinolaryngology-Head and Neck Surgery, College of Medicine, Yeungnam University, Daegu; and \\ ${ }^{2}$ Regional Center for Respiratory Diseases, Yeungnam University Medical Center, Daegu, Korea
}

\section{인간 호흡기 상피세포에서 점액 발현에 대한 Resolvin D1과 E1의 효과}

김형근 $^{1} \cdot$ 최태영 ${ }^{1} \cdot$ 배창훈 $^{1} \cdot$ 최윤석 $^{1} \cdot$ 나형균 $^{1} \cdot$ 송시연 $^{1} \cdot$ 김용대 $^{1,2}$

영남대학교 의과대학 이비인후-두경부외과학교실, ${ }^{1}$ 영남대학교병원 권역 호흡기 전문질환센터 ${ }^{2}$

\footnotetext{
Received March 27, 2018

Revised July 3,2018

Accepted July 9, 2018

Address for correspondence

Yong-Dae Kim, MD, PhD

Department of Otorhinolaryngology-

Head and Neck Surgery,

College of Medicine,

Yeungnam University,

170 Hyeonchung-ro, Nam-gu,

Daegu 42415, Korea

Tel $+82-53-620-3781$

Fax $+82-53-628-7884$

E-mail ydkim@med.yu.ac.kr
}

Background and Objectives Mucin is an important component of mucus that performs the first line of defense against inhaled pathogens and particles, lubrication of organs, and protection of airway. It is hyper-secreted in inflammatory airway diseases and is associated with morbidity and mortality of the affected patients. Resolvin, an autacoid of a specific lipid structure, exhibits anti-inflammatory property against inflammatory airway diseases although its effects on mucin secretion by human airway epithelial cells have not yet been demonstrated. In this regard, we investigated the effects of Resolvin on lipopolysaccharide (LPS)-induced mucin expression in human airway epithelial cells.

Materials and Method In mucin-producing human NCI-H292 epithelial cells, the effects and brief signaling pathways of Resolvin D1 (RvD1) and Resolvin E1 (RvE1) on the LPS-induced MUC4, MUC5AC, and MUC5B expression were investigated using reverse transcription-polymerase chain reaction, enzyme-linked immunosorbent assay and Western blot analysis. Results RvD1 attenuated LPS-induced MUC4, MUC5AC, and MUC5B mRNA expression and protein production in human NCI-H292 cells while RvE1 did not. RvD1 significantly blocked LPS-induced activated phosphorylation of extracellular signal-regulated kinase $1 / 2$ (ERK1/2) mitogen-activated protein kinase (MAPK) and p38 MAPK and nuclear factor kappa-light-chain-enhancer of activated B cells (NF- $\mathrm{B})$ while RvE1 did not.

Conclusion These results suggest that RvD1 attenuates LPS-induced MUC4, MUC5AC, and MUC5B expressions via ERK1/2 MAPK, p38 MAPK, and NF- $\kappa$ B signaling pathways in airway epithelial cells. Therefore, RvD1 may modulate the control of mucus-hypersecretion in inflammatory airway diseases. Korean J Otorhinolaryngol-Head Neck Surg 2019;62(1):28-35

Key Words Human airway epithelial cells $\cdot$ MUC4 $\cdot$ MUC5AC $\cdot$ MUC5B $\cdot$ Resolvin.

\section{서 론}

사람의 호흡기 상피세포 표면을 덮고 있는 점액(mucus)은 젤의 형태로, 세포 외 환경과 세포막 및 세포 내부 사이에서

This is an Open Access article distributed under the terms of the Creative Commons Attribution Non-Commercial License (https://creativecommons.org/licenses/by-nc/4.0) which permits unrestricted non-commercial use, distribution, and reproduction in any medium, provided the original work is properly cited.
선택적인 물리적 장벽 역할을 한다. 점액의 가장 중요한 역할 은 보호와 윤활 및 이송으로, 특히 흡기를 통해 들어온 외부 물질과 세균 등을 섬모운동을 통해 기도로부터 배출함으로 써 방어적인 기능을 한다. ${ }^{1)}$ 그러나 비·부비동염과 천식, 만성 기관지염, 낭종성섬유증 등과 같은 염증성 호흡기 질환에서 는 과다한 점액 분비 또는 점도의 변화로 인하여 병의 이환율 및 사망률을 증가시킬 수 있으므로, 점액이 과다분비 되지 
않게 조절하는 것이 임상적으로 매우 중요하다. ${ }^{2}$ 점액은 물 과 이온, 점소(mucin), 여러 종류의 고분자 물질로 이루어지 는데, 이 중 점소는 점액의 유동학적, 물리화학적, 또는 생화학 적 특성을 결정할 때 가장 큰 영향을 미치는 당단백으로 점 액 유전자에 의해 생성이 조절된다. 현재 사람에서 20여 가지 의 점액 유전자가 발견되었고, 점액 유전자에 의해 발현되는 점액 단백질 구조에 따라 분비형 점소(secreted mucin)와 세 포의 수용체 역할을 하는 막성 점소(transmembrane mucin) 로 크게 나눈다. ${ }^{3}$ 그중 MUC4, MUC5AC, MUC5B와 MUC8 이 호흡기에서 발현되는 중요한 점액 유전자로 알려져 있다. ${ }^{1)}$

사람의 호흡기 상피세포에서 lipopolysaccharide는 그람 음 성 세균의 외막 성분으로 toll-like receptor 4 를 활성화하여 mitogen-activated protein kinase(MAPK) 경로를 통해 대식 세포를 자극시켜 사이토카인을 유도하여 여러 염증 반응을 일으켜서 점액 유전자 발현과 점액 단백 생성을 증가시킨다. ${ }^{4-7)}$

Resolvin은 오메가-3 다중불포화 지방산인 eicosapentaenoic acid(EPA)로부터 합성된 E-series resolvin인 resolvin E (RvE)와 docohexaenoic acid(DHA)로부터 합성된 D-series resolvin인 resolvin $\mathrm{D}(\mathrm{RvD})$ 로 나뉘는데, 이들 지질 매개체는 천식과 만성폐쇄성폐질환, 복막염, 대장염, 피부 염증 등에서 강력한 항염증 작용 및 염증의 해소를 유발하는 과정인 proresolving 효과를 나타내어 염증 억제 및 해소 작용을 보인 다. ${ }^{8)}$ 그러나 염증성 호흡기 질환에서 점액 유전자 발현에 있어 resolvin이 어떤 영향을 미치는지에 대한 연구는 아직까지 미미한 상태이다.

따라서 인간 호흡기 상피세포인 NCI-H292 세포를 이용하여 resolvin이 LPS에 의해 유도된 MUC4, MUC5AC와 MUC5B 점액 유전자의 발현과 점액 단백 생성에 대한 영향과 신호전 달 체계를 알아보고자 이 연구를 시행하였다.

\section{재료 및 방법}

\section{재 료}

RvD1과 RvE1은 Cayman Chemical(Ann Arbor, MI, USA) 에서 구입하였고, LPS는 Sigma(St. Louis, MO, USA)에서 구입 하였다. RPMI 1640 medium은 Invitrogen(Carlsbad, CA, USA) 에서 구입하였고, fetal bovine serum(FBS)은 Hyclone Laboratories(Logan, UT, USA)에서 구입하였다. MUC4(354900) 일차항체는 Invitrogen에서 구입하였고, MUC5AC(SC-20118) 와 MUC5B(SC-20119) 일차항체 및 goat anti-mouse or goat anti-rabbit horseradish peroxidase(HRP)-conjugated 이차 항체, p38 항체는 Santa Cruz Biotechnology(Santa Cruz, $\mathrm{CA}, \mathrm{USA}$ )에서 구입하였다. Extracellular signal-regulated
kinase(ERK)1/2 MAPK와 phospho-ERK1/2 MAPK, phospho-p38 MAPK, nuclear factor kappa-light-chainenhancer of activated $B$ cells $(\mathrm{NF}-\kappa \mathrm{B})$, phospho- $-\mathrm{NF}-\kappa \mathrm{B}$ 는 Cell Signaling Technology(Danvers, MA, USA)에서 구 입하였다.

\section{세포 배양 및 처치}

점액 분비를 일으키는 사람 폐의 점액상피양 암 세포주(human pulmonary mucoepidermoid carcinoma cell line)인 NCI-H292 세포(American Type Culture Collection, Manassas, VA, USA)를 6-well plate에 $1 \times 10^{6}$ cells/well의 농도로 접종한 후 $1 \%$ penicillin/streptomycin과 $10 \% \mathrm{FBS}$ 가 포함 된 RPMI 1640 배지를 이용하여 $95 \%$ 의 산소와 $5 \%$ 의 이산화 탄소가 혼합된 배양기에서 $37^{\circ} \mathrm{C}$ 의 온도로 배양하였다. 70 $80 \%$ 정도의 융합기에 이르면 세포를 $0.5 \%$ fetal calf serum 이 포함된 RPMI 1640 배지로 교체하여 24시간 동안 배양 후 실험을 진행하였다. 실험에서 사용한 NCI-H292 세포에 대한 RvD1과 RvE1의 세포독성 유무 확인과 전처치 농도를 결정하기 위해 EZ-Cytox Cell Viability Assay Kit(Daeil Laboratories., Seoul, Korea)를 이용한 세포독성 검사와 현미경 을 통한 세포 형태 변화 유무를 다양한 농도 $(0,50,100,200$, $500 \mathrm{nM}$ )에서 확인하였으며 50, 100, $200 \mathrm{nM}$ 의 농도에서는 세포 독성이 나타나지 않았으나, RvD1과 RvE1 모두 $500 \mathrm{nM}$ 농도에서는 유의미한 세포독성이 관찰되었으며, resolvin의 효과에 대한 최근 선행연구들의 연구결과를 참고하여 100 $\mathrm{nM}$ 과 $200 \mathrm{nM}$ 두 농도의 RvD1과 RvE1을 전처치하였다.,10) Resolvin을 전처리한 NCI-H292 세포는 1시간 뒤에 $100 \mathrm{ng} /$ $\mathrm{mL}$ 농도의 LPS를 다시 노출시켜 배양하였다.

\section{RT-PCR 분석}

Gene Amp RNA polymerase chain reaction(PCR) core kit(Applied Biosystems, Carlsbad, CA, USA)와 T100TM Thermal Cycler(Bio-Rad, Hercules, CA, USA) PCR 기계를 사용하여 제조사의 방법대로 시행하였다. PCR에 사용된 oligonucleotide primer는 인체 MUC4, MUC5AC와 MUC5B 점액 유전자의 sense와 antisense를 사용하였으며, 각 반응의 내부 양성 대조군은 glyceraldehyde-3-phosphate dehydrogenase를 사용하였다.

Reverse transcription-PCR 과정을 간략히 설명하면, 배 양된 세포를 phosphate buffered saline(PBS)로 3회 세척한 후 $\operatorname{Trizol}^{\circledR}$ (Invitrogen)을 이용하여 총 mRNA를 추출하였다. MUC4, MUC5AC와 MUC5B mRNA에 대한 PCR은 $95^{\circ} \mathrm{C}$ 에 서 60 초간 변성 과정과 $60^{\circ} \mathrm{C}$ 에서 30 초간 결합 반응, $72^{\circ} \mathrm{C}$ 에서 
60 초간 연장 반응을 30 회 반복한 후 $72^{\circ} \mathrm{C}$ 에서 20 분간 최종 연장 반응을 시행하였다. 증폭된 중합효소연쇄반응의 산물 은 SYBR green이 함유된 2\% agarose gel을 통한 전기영동을 이용하여 분리 관찰하였다. 전기영동 결과를 imaging system (Chemiluminescence Image System, Vilber, FUSION-FX7820. WL, Marne-la-Vallée, France)로 확인하였고, 대조군 의 density를 100으로 하였을 때 실험군의 density 값을 비율 로 나타내어 relative density로 나타내었다.

\section{면역분석법(Immunoassay)}

$\mathrm{MUC4}, \mathrm{MUC5AC}$ 와 MUC5B의 점액 단백의 함량을 측정 하기 위해서 enzyme-linked immunosorbent assay(ELISA) 법을 이용하였다. 시료를 처리한 배양된 세포에서 $200 \mu \mathrm{L}$ RIPA buffer(Thermo Fisher, Rockford, IL, USA)로 단백을 추출하여 정량하였다. 추출한 단백질을 F96 Cert. Maxisorp Nunc-Immuno Plate(Thermo Scientific, Lenexa, KS, USA) 에 코팅한 후 $4^{\circ} \mathrm{C}$ 에서 하루 배양하였다. 비특이적 결합을 방 지하기 위해 $2 \%$ bovine serum albumin(BSA)이 들어있는 $\mathrm{PBS}$ 로 실온에서 1시간 동안 둔 다음, $0.05 \%$ Tween 20을 함유 한 PBS에 세척한 다음 1:200으로 희석된 MUC4, MUC5AC 와 MUC5B 일차항체로 반응시켰다. 3회 세척한 후 HRPconjugated 된 이차항체를 $2 \% \mathrm{BSA}$ 가 함유된 PBS에 1:1000 으로 희석하여 각 well에 첨가하였고, 1 시간 후에 각 well을 3회 세척하였다. 3,3, 5,5-tetramethyl benzidine 용액으로 발
색한 후, $2 \mathrm{~N}-\mathrm{H}_{2} \mathrm{SO}_{4}$ 를 이용하여 중단시켰다. ELISA reader $\left(\mathrm{EL} 80{ }^{\circledR}\right.$, BIO-TEK Instruments, Winooski, VT, USA)로 $450 \mathrm{~nm}$ 에서 흡광도를 측정한 후 결과 값을 100 을 기준으로 나타내었다.

\section{Western blot 분석}

$\mathrm{ERK} 1 / 2, \mathrm{p} 38 \mathrm{MAPK}$ 와 $\mathrm{NF}-\kappa \mathrm{B}$ 의 활성도를 측정하기 위 해 Western blot 분석법을 이용하였다. NCI-H292 세포를 6-well plate에 담고 농도에 따라 각각 RvD1와 RvE1을 처리 하여 배양하였다. 이후 각 세포들을 $200 \mu \mathrm{L}$ RIPA buffer를 이용하여 단백질을 모은 다음 $4^{\circ} \mathrm{C}$ 에서 $2500 \times \mathrm{g}$ 으로 10 분간 원 심분리하여 상층액을 얻어 실험을 진행하였다. 추출한 단백 $20 \mu \mathrm{g}$ 은 10\% reducing sodium dodecyl sulfate- polyacrylamide gel을 이용해 전기영동하여 분리하였으며 polyvinylidene difluoride membrane으로 옮겼다. 이를 다시 $5 \%$ nonfat dry milk로 차단하여 ERK1/2 MAPK, p38 MAPK와 NF- $\kappa \mathrm{B}$ 일차항체로 반응시킨 후 각각 4시간씩 처리한 다음 $\mathrm{ERK} 1 / 2$ $\mathrm{MAPK}, \mathrm{p} 38 \mathrm{MAPK}$ 와 $\mathrm{NF}-\kappa \mathrm{B}$ 이차항체를 처리하여 1 시간 두었다. Tris buffered saline with $0.1 \%$ Tween 20 를 이용하 여 3회 세척한 후 West Pico Chemiluminescent Substrate (Thermo Fisher)를 이용하여 imaging system으로 각각의 띠 (band)를 확인하였다. 감광된 띠의 세기는 반정량적으로 분 석하여 상대적인 density로 나타내었다.

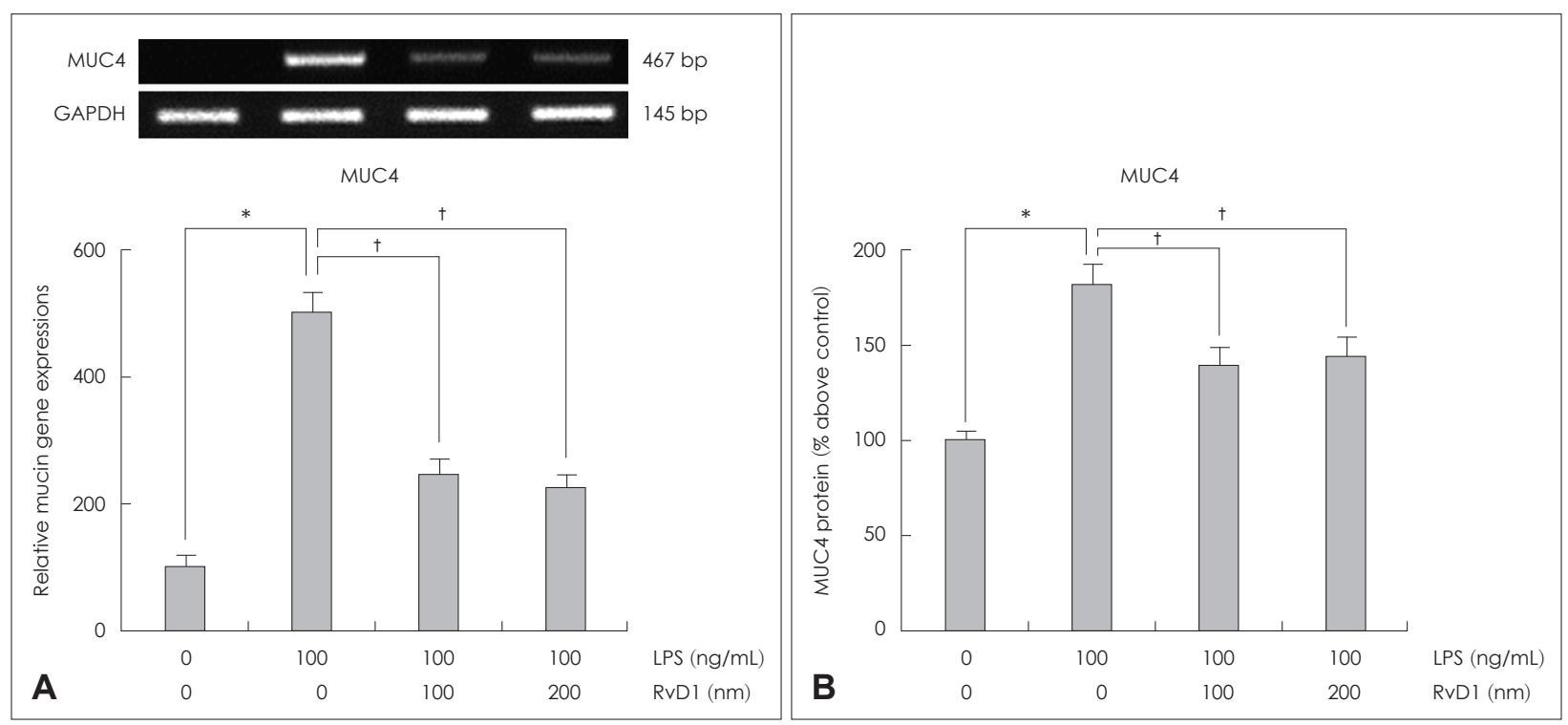

Fig. 1. The effects of RvD1 on LPS-induced MUC4 expression in human $\mathrm{NCl}-\mathrm{H} 292$ cells. The results of reverse transcription-polymerase chain reaction showed that RvD1 significantly attenuated LPS-induced MUC4 mRNA expression (A). The results of enzymelinked immunosorbent assay showed that RVD1 significantly decreased LPS-induced MUC4 protein production (B). Images are representative of three separate experiments performed in triplicate. Bars indicate the mean \pm standard deviation of three independent experiments performed in triplicate. ${ }^{*} p<0.05$ compared with zero value, ${ }^{\dagger} p<0.05$ compared with LPS only. LPS: lipopolysaccharide, GAPDH: glyceraldehyde-3-phosphate dehydrogenase, RvD: resolvin D. 
통 계

통계 처리는 Windows용 SPSS version 10.0(SPSS Inc., Chicago, IL, USA)을 사용하였다. 모든 실험은 $p$ 값이 0.05 미만인 경우를 유의한 것으로 정하여 Student's t-test와 analysis of variance, Mann-Whitney U test를 이용하였다.

\section{결 과}

$\mathrm{NCI}-\mathrm{H} 292$ 세포에서 RvD1이 LPS에 의해 유도된 MUC4, MUC5AC와 MUC5B mRNA 발현과 점액 단백 생성에 미 치는 영향

두 농도의 RvD1(100 nM과 $200 \mathrm{nM})$ 이 LPS에 의해 유도된 MUC4 mRNA 발현과 점액 단백 생성에 미치는 효과를 확 인해 본 결과, 두 농도 모두에서 LPS에 의해 유도된 MUC4 $\mathrm{mRNA}$ 과발현과 점액 단백 과생성을 RvD1이 의미 있게 감 소시킨다는 것을 PCR 검사와 ELISA 검사를 통해 확인할 수 있었으며, 두 농도 간의 효과 차이는 없었다(Fig. 1). 또한 LPS 에 의해 유도된 분비형 점액 유전자인 MUC5AC mRNA와 MUC5B mRNA 발현과 단백 생성에 미치는 RvD1의 효과를 확인한 실험에서도 RvD1 두 농도 모두에서 LPS에 의해 유도 된 MUC5AC mRNA와 MUC5B mRNA 과발현과 점액 단 백 과생성을 의미 있게 감소시킨다는 것을 확인할 수 있었고,
두 농도 간의 효과 차이는 없었다(Fig. 2).

NCI-H292 세포에서 RvE1이 LPS에 의해 유도된 MUC4, MUC5AC와 MUC5B mRNA 발현과 점액 단백 생성에 미 치는 영향

두 농도의 RvE1(100 nM과 $200 \mathrm{nM})$ 이 LPS에 의해 유도된 MUC4 mRNA 발현과 점액 단백 생성에 미치는 효과를 확인 해 본 결과, RvD1과는 다르게 RvE1은 두 농도 모두에서 LPS 에 의해 유도된 MUC4 mRNA 과발현과 점액 단백 과생성 을 의미 있게 감소시키지 못하였다(Fig. 3). 또한 LPS에 의해 유도된 분비형 점액 유전자인 MUC5AC mRNA와 MUC5B $\mathrm{mRNA}$ 발현과 단백 생성에 미치는 RvE1의 효과를 확인한 실험에서도 RvE1은 LPS에 의해 유도된 MUC5AC mRNA와 MUC5B mRNA 과발현과 점액 단백 과생성을 의미 있게 억 제하지 못한다는 것을 확인할 수 있었다(Fig. 4).

\section{$\mathrm{NCI}-\mathrm{H} 292$ 세포에서 RvD1과 RvE1이 LPS에 의해 유도된} $\mathrm{ERK} 1 / 2 \mathrm{MAPK}, \mathrm{p} 38 \mathrm{MAPK}$ 와 $\mathrm{NF}-\mathrm{\kappa B}$ 의 인산화에 미치 는 영향

$\mathrm{RvD1}$ 과 RvE1이 LPS에 의해 유도되는 점액 유전자 과발 현의 중요 신호전달물질인 ERK1/2 MAPK, p38 MAPK와 $\mathrm{NF}-\kappa \mathrm{B}$ 활성화에 미치는 효과를 Western blot 검사로 확인

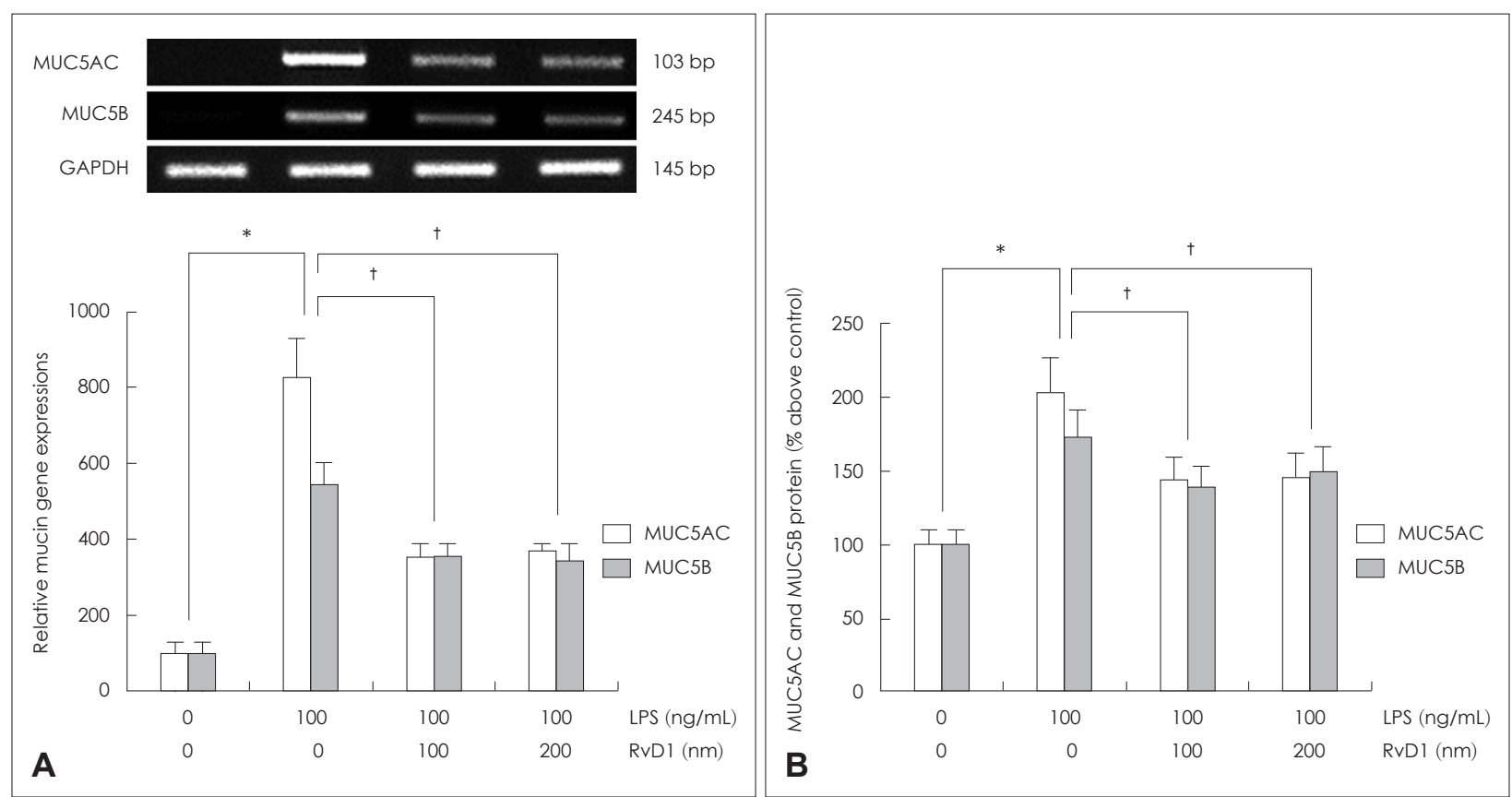

Fig. 2. The effects of RvD1 on LPS-induced MUC5AC and MUC5B expression in human NCl-H292 cells. The results of reverse transcription-polymerase chain reaction showed that RVD1 significantly attenuated LPS-induced MUC5AC and MUC5B mRNA expression (A). The results of enzyme-linked immunosorbent assay showed that RvD1 significantly decreased LPS-induced MUC5AC and MUC5B protein production (B). Images are representative of three separate experiments performed in triplicate. Bars indicate the mean \pm standard deviation of three independent experiments performed in triplicate. ${ }^{*} p<0.05$ compared with zero value, ${ }^{\dagger} p<0.05$ compared with LPS only. LPS: lipopolysaccharide, GAPDH: glyceraldehyde-3-phosphate dehydrogenase, RvD: resolvin D. 
해 본 결과, RvD1은 두 농도 모두에서 LPS에 의해 유도된 $\mathrm{ERK} 1 / 2 \mathrm{MAPK}, \mathrm{p} 38 \mathrm{MAPK}$ 와 $\mathrm{NF}-\kappa \mathrm{B}$ 인산화를 모두 의미 있게 감소시킴을 확인할 수 있었으며, 두 농도 간의 효과 차이
는 없었다(Fig. 5A). 그러나 RvE1를 이용한 실험에서는 LPS 에 의해 유도된 ERK1/2 MAPK, p38 MAPK와 NF- $\kappa \mathrm{B}$ 인 산화를 모두 의미 있게 감소시키지 못한다는 것을 확인할 수

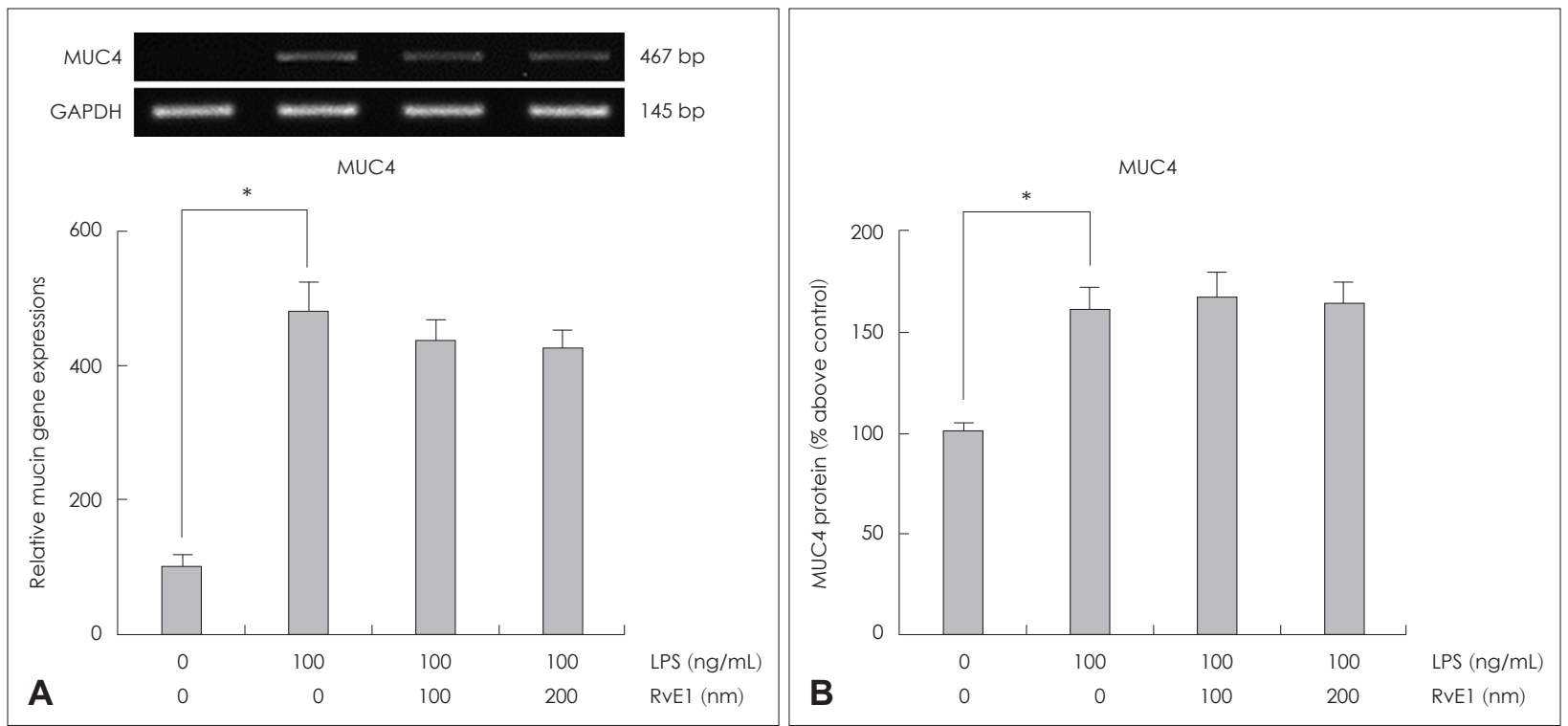

Fig. 3. The effects of RvE1 on LPS-induced MUC4 expression in human NCl-H292 cells. The results of reverse transcription-polymerase chain reaction showed that RvE1 did not attenuate LPS-induced MUC4 mRNA expression (A). The results of enzyme-linked immunosorbent assay showed that RVE1 did not decrease LPS-induced MUC4 protein production (B). Images are representative of three separate experiments performed in triplicate. Bars indicate the mean \pm standard deviation of three independent experiments performed in triplicate. ${ }^{*} p<0.05$ compared with zero value. LPS: lipopolysaccharide, GAPDH: glyceraldehyde-3-phosphate dehydrogenase, RvE: resolvin E.

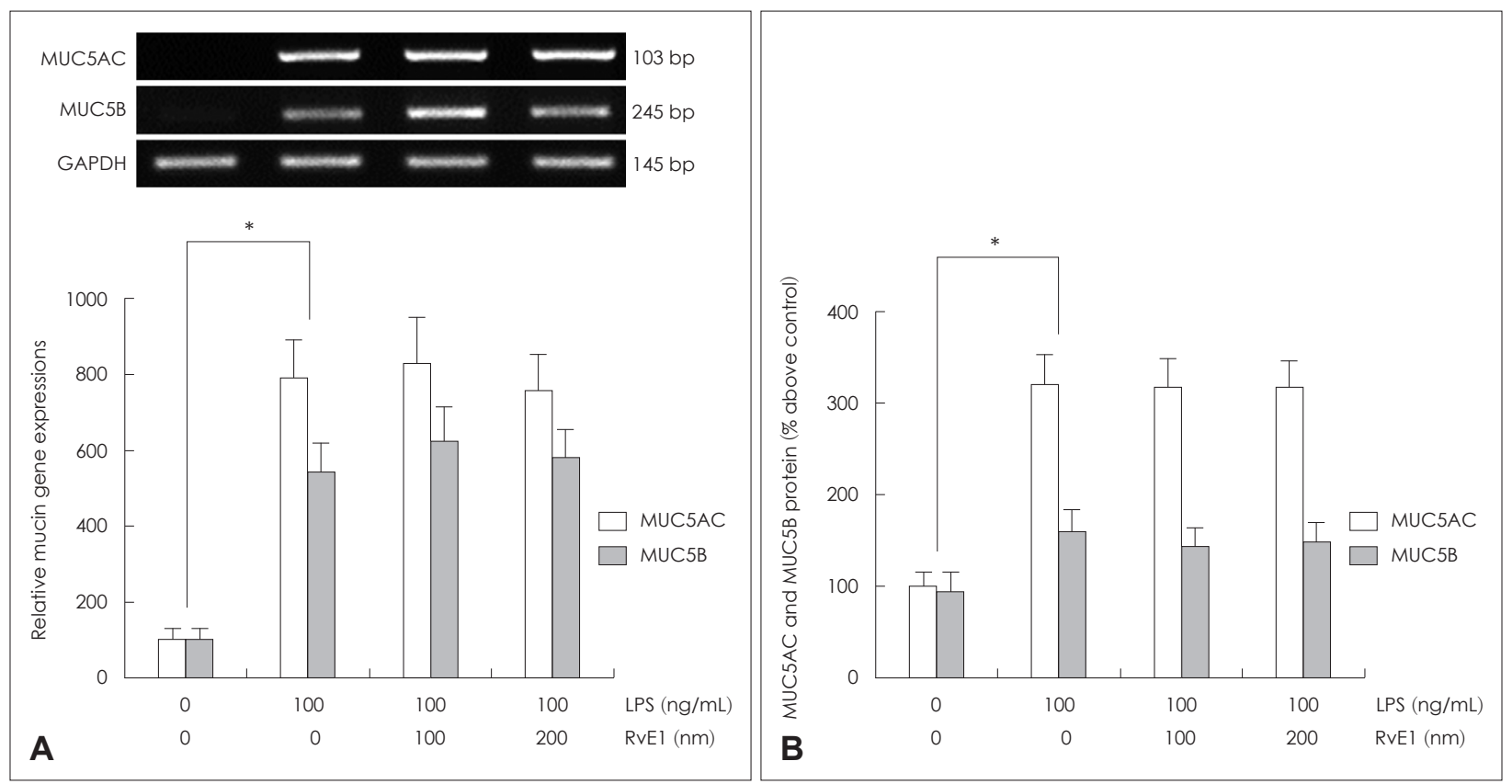

Fig. 4. The effects of RvE1 on LPS-induced MUC5AC and MUC5B expression in human NCl-H292 cells. The results of reverse transcription-polymerase chain reaction showed that RvE1 did not attenuate LPS-induced MUC5AC and MUC5B mRNA expression (A). The results of enzyme-linked immunosorbent assay showed that RVE1 did not decrease LPS-induced MUC5AC and MUC5B protein production (B). Images are representative of three separate experiments performed in triplicate. Bars indicate the mean \pm standard deviation of three independent experiments performed in triplicate. ${ }^{*} p<0.05$ compared with zero value. LPS: lipopolysaccharide, GAPDH: glyceraldehyde-3-phosphate dehydrogenase, RvE: resolvin E. 

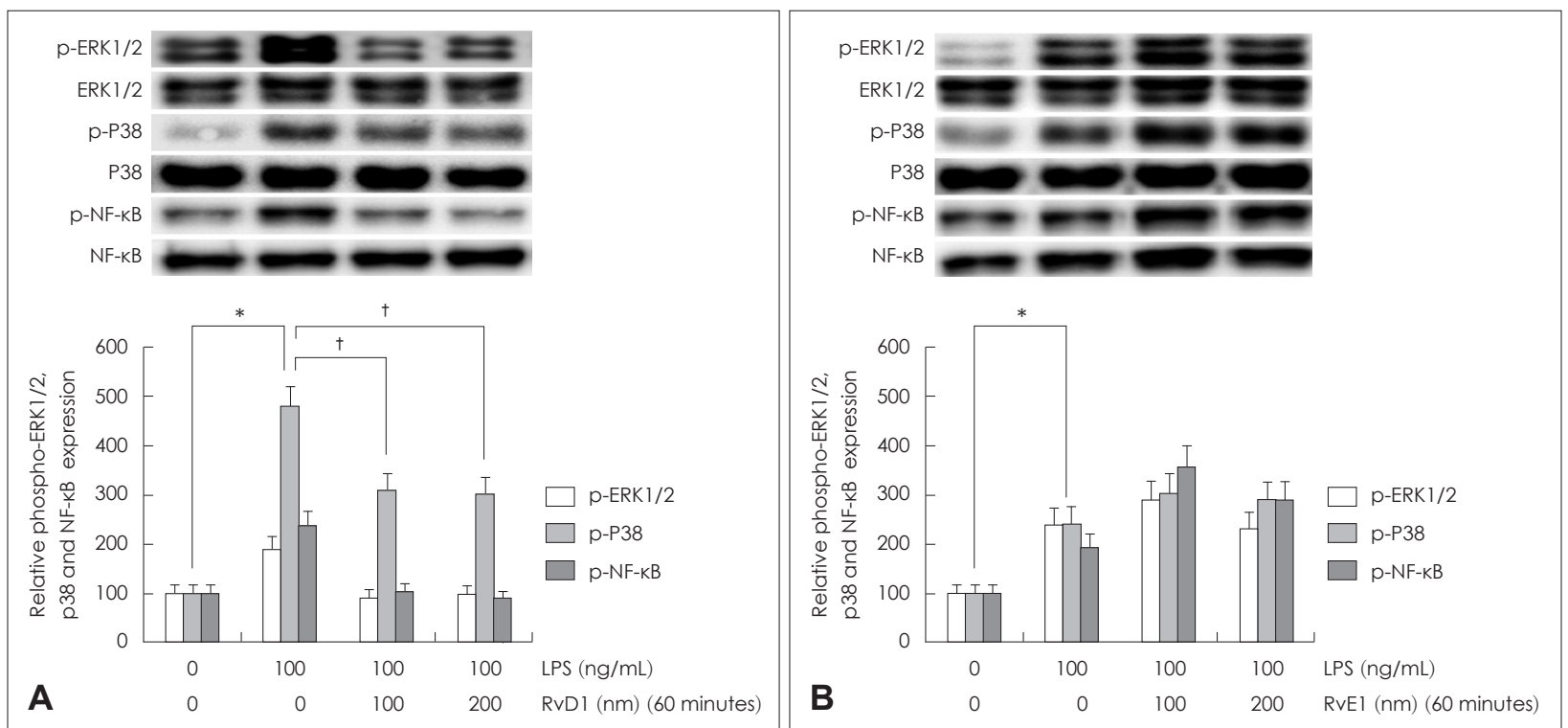

Fig. 5. The effects of RvD1 and RvE1 on phosphorylation of ERK1/2 MAPK, p38 MAPK, and NF-KB by LPS in human NCI-H292 cells. In NCI-H292 cells, the results of Western blot showed that RVD1 significantly decreased LPS-induced phosphorylated ERK1/2 MAPK, p38 MAPK and NF-KB (A), while RvE1 did not (B). Images are representative of three separate experiments performed in triplicate. Bars indicate the mean \pm standard deviation of three independent experiments performed in triplicate. ${ }^{*} p<0.05$ compared with zero value, ${ }^{\dagger} p<0.05$ compared with LPS only. LPS: lipopolysaccharide, MAPK: mitogen activated protein kinase, ERK1/2: extracellular regulated kinase 1/2, p-ERK1/2: phosphorylated extracellular regulated kinase 1/2, p-p38: phosphorylated p38, NF-KB: nuclear factor-kB, p-NF-kB: phosphorylated nuclear factor-kB, RvD: resolvin D, RvE: resolvin E.

있었다(Fig. 5B).

\section{고 찰}

염증은 조직 손상이나 감염에 대한 인체의 초기 방어기전으 로, 염증의 개시부터 해소까지 다양한 매개체들이 관여한다. 염증 반응이 해소되는 과정은 전염증성 매개체(pro-inflammatory mediator) 신호전달 경로의 종결과 염증 세포의 제거 를 통해 의해 이루어지는 것으로 알려져 있었지만, 최근에는 resolvin과 lipoxin 등의 내인성 물질이 염증의 해소를 유발하 는 과정인 pro-resolving 작용을 하여 능동적으로 조절하는 것으로 인식되고 있다.

Resolvin은 오메가-3 다중불포화 지방산인 EPA와 DHA 로부터 합성된다. RvD1은 혈관내피세포에서 아세틸화된 cyclooxygenase-2에 의해 DHA가 17R-hydroxy-DHA로 전환되고 이는 백혈구 내 5-lipoxygenase에 의해 RvD1으로 합성되고, RvE1도 유사하게 합성된다. ${ }^{11,12)}$ 이렇게 합성된 RvD1과 RvE1은 세포막에 존재하는 G-protein coupled receptor를 통해 여러 경로에 작용하여 염증 신호 전달 단백질 인 NF- $\kappa \mathrm{B}$ 를 억제하고 전염증성 사이토카인의 분비를 저해 하여 염증 해소를 촉진시킨다. ${ }^{13,14)}$ 또한 최근 연구에 따르면 임상적으로 오메가-3 다중불포화 지방산이 풍부한 음식물 을 섭취 시 만성폐쇄성폐질환 또는 천식과 같은 폐질환의 치
료에 도움이 된다고 밝혀졌으며, ${ }^{15)}$ 특히 resolvin은 복막염, 대 장염, 피부 염증과 같은 질환에서 항염증 작용 및 pro-resolving 효과가 있는 것으로 알려져 있다. ${ }^{16-19)}$ 또한, 호흡기 질환 모델인 폐렴과 천식 마우스 모델에서도 기도의 과반응성 및 염증을 감소시키는 효과가 있음이 확인되었다. ${ }^{20,211}$ 본 연구에 서는 강력한 항염증 효과가 알려져 있는 RvD1과 RvE2이 염 증성 호흡기 질환에서 점액 분비의 억제에 미치는 효과를 확 인하고자 하였고, RvD1이 LPS에 의해 유도되는 중요 막성 점 액 단백인 MUC4와 분비형 점액 단백인 MUC5AC와 MUC5B 의 과생성을 의미 있게 감소시킴을 확인할 수 있었으며, 전처 치 농도인 $100 \mathrm{nM}$ 과 $200 \mathrm{nM}$ 의 억제 효과는 차이가 없었다. 이는 $\mathrm{RvD} 1$ 의 점액 단백 과생성 억제 효과가 전처치 농도보 다 낮은 농도에서 나타나거나 RvD1의 효과가 농도 의존성을 보이지 않아 그럴 것으로 추측된다. 그러나 RvE1은 LPS에 의해 유도된 세 가지 점액 단백 과생성을 모두 억제하지 못하 였다. 이를 통해 우리는 점액 과분비의 중요한 인자인 점액 단 백 과생성이 resolvin과 같은 내인성 물질에 의해 조절될 수 있으며, 그 효과는 resolvin의 종류에 따라 다소 차이가 있을 것으로 생각된다. 특히 본 연구에서는 RvD1이 LPS에 의해 유 도된 다양한 호흡기 점액 단백의 과생성을 강하게 억제하는 것을 확인할 수 있었다.

점소(mucin)는 점액의 점성과 탄성에 영향을 미치는 주요 한 인자로, 적절한 점소의 생성은 호흡기 상피세포에서 점막섬 
모 운동 기능을 유지하는 데 있어 매우 중요하다. 비·부비동 염과 천식, 만성폐쇄성폐질환, 낭종성 섬유증 등과 같은 호흡 기 염증성 질환에서 이러한 점액 단백의 비정상적인 분비 및 축적이 관찰되며, 호흡기 점막에서 점액 단백의 분비를 증가 시키는 대표적인 염증성 매개 물질로는 LPS, phorbol myristate acetate, 다양한 interleukin 등이 알려져 있다. ${ }^{7}$ 그중 $\mathrm{LPS}$ 는 그람 음성 세균의 외막 성분으로 체내에서 MAPK 경로와 $\mathrm{NF}-\kappa \mathrm{B}$ 등의 활성화를 통해 호흡기 상피세포에서 다양한 점액 유전자의 과발현을 유도하는 것으로 알려져 있 다. ${ }^{22-25)}$ 본 연구에서도 LPS는 호흡기 상피세포에서 막형 점 소인 MUC4와 분비형 점소인 MUC5AC와 MUC5B의 과생 성을 유도하였으며, 또한 점액 단백의 과생성에 관여하였을 것으로 생각되는 $\mathrm{ERK} 1 / 2, \mathrm{p} 38 \mathrm{MAPK}$ 와 $\mathrm{NF}^{-} \kappa \mathrm{B}$ 의 등의 신 호전달 물질을 활성화 시킴을 확인할 수 있었다. 또한 이러한 신호전달 물질의 활성화는 점액 단백 과생성에 대해 강한 억 제 효과를 보였던 RvD1에 의해서 의미 있게 억제되는 것으 로 보아 RvD1이 LPS에 의해 활성화된 다양한 신호전달 과 정을 억제함으로써 호흡기 점액 단백 과생성을 감소시킨다는 것을 확인할 수 있었다.

본 연구의 결과로 RvD1은 LPS에 의해 유도된 점액 단백의 과생성을 억제하는 효과가 있으며, 이는 LPS에 의한 점액 과 생성에 주로 관여하는 것으로 알려진 ERK1/2 MAPK, p38 $\mathrm{MAPK}$ 와 $\mathrm{NF}-\kappa \mathrm{B}$ 신호전달 경로의 조절을 통해 이루어지는 것으로 생각된다. 하지만 사람의 호흡기 상피세포에서 RvD1 의 점액 유전자 발현 및 점액 단백 생성의 억제를 명확히 알 기 위해서는 다른 종류의 세포나 동물을 이용하여 보다 다양 한 점액 유전자 및 단백의 발현 양상과 신호전달 체계에 대 한 연구가 추가되어야 할 것으로 생각된다.

결론적으로 본 연구를 통해 호흡기 상피세포에서 RvD1이 점액의 성상에 영향을 주는 점액 단백 생성을 억제하는 효과 가 있음을 확인할 수 있었으며, 이는 염증성 호흡기질환 악 화의 주요 병인 중 하나인 점액 단백 과생성을 억제할 수 있 는 치료 후보물질로서의 RvD1의 가능성을 확인한 기초 연 구로 생각된다.

\section{REFERENCES}

1) Ali MS, Pearson JP. Upper airway mucin gene expression: a review. Laryngoscope 2007;117(5):932-8.

2) Williams OW, Sharafkhaneh A, Kim V, Dickey BF, Evans CM. Airway mucus: from production to secretion. Am J Respir Cell Mol Biol 2006;34(5):527-36.

3) Rose MC, Voynow JA. Respiratory tract mucin genes and mucin glycoproteins in health and disease. Physiol Rev 2006;86(1):245-78.

4) Usui S, Shimizu T, Kishioka C, Fujita K, Sakakura Y. Secretory cell differentiation and mucus secretion in cultures of human nasal epithelial cells: use of a monoclonal antibody to study human nasal mucin.
Ann Otol Rhinol Laryngol 2000;109(3):271-7.

5) Zhao S, Zhang L, Lian G, Wang X, Zhang H, Yao X, et al. Sildenafil attenuates LPS-induced pro-inflammatory responses through downregulation of intracellular ROS-related MAPK/NF- $\mathrm{KB}$ signaling pathways in N9 microglia. Int Immunopharmacol 2011;11(4):468-74.

6) Dauphiness SM, Karsan A. Lipopolysaccharide signaling in endothelial cells. Lab Invest 2006;86(1):9-22.

7) Kim HS, Choi YS, Lee JH, Park NK, Park CH, Lee YH, et al. Effect of betulinic acid on MUC5AC and MUC5B expression in airway epithelial cells. Korean J Otorhinolaryngol-Head Neck Surg 2014;57 (8):526-32.

8) Serhan CN. Novel lipid mediators and resolution mechanisms in acute inflammation: to resolve or not? Am J Pathol 2010;177(4): 1576-91.

9) Hsiao HM, Thatcher TH, Levy EP, Fulton RA, Owens KM, Phipps $\mathrm{RP}$, et al. Resolvin D1 attenuates polyinosinic-polycytidylic acidinduced inflammatory signaling in human airway epithelial cells via TAK1. J Immunol 2014;193(10):4980-7.

10) Baker LA, Martin NRW, Kimber MC, Pritchard GJ, Lindley MR, Lewis MP. Resolvin E1 (Rv E1) attenuates LPS induced inflammation and subsequent atrophy in C2C12 myotubes. J Cell Biochem 2018; 119(7):6094-103.

11) Serhan CN, Petasis NA. Resolvins and protectins in inflammation resolution. Chem Rev 2011;111(10):5922-43.

12) Zhang MJ, Spite M. Resolvins: anti-inflammatory and proresolving mediators derived from omega-3 polyunsaturated fatty acids. Annu Rev Nutr 2012;32:203-27.

13) Ishida T, Yoshida M, Arita M, Nishitani Y, Nishiumi S, Masuda A, et al. Resolvin E1, an endogenous lipid mediator derived from eicosapentaenoic acid, prevents dextran sulfate sodium-induced colitis. Inflamm Bowel Dis 2010;16(1):87-95.

14) Krishnamoorthy S, Recchiuti A, Chiang N, Yacoubian S, Lee CH, Yang R, et al. Resolvin D1 binds human phagocytes with evidence for proresolving receptors. Proc Natl Acad Sci U S A 2010;107(4): $1660-5$.

15) Shahar E, Folsom AR, Melnick SL, Tockman MS, Comstock GW, Gennaro V, et al. Dietary n-3 polyunsaturated fatty acids and smokingrelated chronic obstructive pulmonary disease. Atherosclerosis Risk in Communities Study Investigators. N Engl J Med 1994;331(4): 228-33.

16) Sun YP, Oh SF, Uddin J, Yang R, Gotlinger K, Campbell E, et al. Resolvin D1 and its aspirin-triggered 17R epimer. Stereochemical assignments, anti-inflammatory properties, and enzymatic inactivation. J Biol Chem 2007;282(13):9323-34.

17) Arita M, Yoshida M, Hong S, Tjonahen E, Glickman JN, Petasis NA, et al. Resolvin E1, an endogenous lipid mediator derived from omega-3 eicosapentaenoic acid, protects against 2,4,6-trinitrobenzene sulfonic acid-induced colitis. Proc Natl Acad Sci U S A 2005;102(21): 7671-6.

18) Serhan CN, Hong S, Gronert K, Colgan SP, Devchand PR, Mirick G, et al. Resolvins: a family of bioactive products of omega-3 fatty acid transformation circuits initiated by aspirin treatment that counter proinflammation signals. J Exp Med 2002;196(8):1025-37.

19) Chen YF, Jiang H, Gong X, Wan JY. Resolvin E1 protects against oxLDL-induced injury on vascular endothelial cells. Zhonghua Xin Xue Guan Bing Za Zhi 2011;39(11):1039-43.

20) Seki H, Fukunaga K, Arita M, Arai H, Nakanishi H, Taguchi R, et al. The anti-inflammatory and proresolving mediator resolvin E1 protects mice from bacterial pneumonia and acute lung injury. J Immunol 2010;184(2):836-43.

21) Levy BD, Kohli P, Gotlinger K, Haworth O, Hong S, Kazani S, et al. Protectin D1 is generated in asthma and dampens airway inflammation and hyperresponsiveness. J Immunol 2007;178(1):496-502.

22) Thai P, Loukoianov A, Wachi S, Wu R. Regulation of airway mucin 
gene expression. Annu Rev Physiol 2008;70:405-29.

23) Park NK, Choi YS, Lee JH, Kim HS, Kim JK, Ahn JH, et al. Effect of udenafil on MUC5B expression in human airway epithelial cells. Korean J Otorhinolaryngol-Head Neck Surg 2013;56(8):501-5.

24) Wang Y, Shen Y, Li K, Zhang P, Wang G, Gao L, et al. Role of matrix metalloproteinase-9 in lipopolysaccharide-induced mucin production in human airway epithelial cells. Arch Biochem Biophys 2009;486 (2):111-8.

25) Bai CH, Song SY, Kim YD. Effect of glucocorticoid on the MUC4 gene in nasal polyps. Laryngoscope 2007;117(12):2169-73. 